\title{
GANGGUAN DISFUNGSI SEKSUAL DITINJAU DARI LAMA PENGGUNAAN KB IMPLANT DI KELURAHAN SUKARAYA PADA TAHUN 2021
}

\section{SEXUAL DYSFUNCTION DISORDERS JUDGING FROM THE LENGTH OF USE OF KB IMPLANTS IN SUKARAYA VILLAGE IN 2021}

\author{
$\underline{\text { Yeviza Puspitasari }}{ }^{1}, \underline{\text { Yustina Oktarida }}^{2}$ \\ Sekolh Tinggi Ilmu Kesehatan Al-Ma;arif Jl. Dr Muhammad Hatta No.687 B Sukaraya ${ }^{12}$ \\ e-mail: yeviza.puspitasari1402@gmail.com ${ }^{1}$, yustinaoktarida647@gmail.com ${ }^{2}$
}

\begin{abstract}
ABSTRAK
Jenis penelitian ini adalah survey analitik dengan pendekatan cross sectional. Populasi adalah semua akseptor KB Implan di Kelurahan Sukaraya Wilayah Kerja Puskesmas Sukaraya Tahun 2021, dengan Stratified Random Sampling dan analisa penelitian dengan menggunakan analisa univariat dan bivariat dengan Uji Chi-Square. Analisa hasil penelitian dari 54rersponden Mayoritas responden yang menggunakan KB Implan lebih dari 12 bulan yaitu sebanyak 43 responden (79,63\%), dan minoritas responden yang menggunakan KB Implan kurang dari 12 bulan sebanyak 11 responden (20,37\%), dari 54 akseptor KB implan yang mengalami gangguan penurunan hasrat seksual sebanyak 23 akseptor (42,59\%) dan yang tidak mengalami gangguan penurunan hasrat seksual sebanyak 31 akseptor (57,41\%). Dari 54 akseptor KB Implan yang mengalami gangguan orgasme sebanyak 46 akseptor $(85,18 \%)$ dan yang tidak mengalami gangguan orgasme sebanyak akseptor 8 (14,82\%). Dari Hasil analisis bivariat didapatkan akseptor KB implant lama sebanyak 43 akseptor $(79,63 \%)$ dan akseptor KB implant baru sebanyak 11akseptor (20,37\%). Distribusi frekuensi akseptor KB implan yang mengalami gangguan penurunan hasrat seksual sebanyak 23 akseptor (42,59\%) dan yang tidak mengalami gangguan penurunan hasrat seksual sebanyak 31 akseptor (57,41\%). Distribusi frekuensi akseptor KB Implan yang mengalami gangguan orgasme sebanyak 46 akseptor $(85,18 \%)$ dan yang tidak mengalami gangguan orgasme sebanyak 8 akseptor (14,82\%).Tidak ada hubungan antara Penggunaan KB implant dengan kejadian disfungsi seksual (gangguan penururnan hasrat seksual dan gangguan orgasme).
\end{abstract}

Kata kunci: Implan, DisfungsiSeksual.

\begin{abstract}
This type of research is an analytic survey with cross sectional findings. Population of all implant KB acceptors in the, with sexual dysfunction in the village Sukaraya area of Puskesmas Sukaraya district at 2021 with ChiSquare Test. Analysis of the research results of 54 respondents the majority of respondents who used KB implants less than 12 months, as many as 43 respondents (79,63\%), and the mayorty of respondents who used KB implants less than 12 months were 11 respondents (20,37\%), out of KB acceptors Implants that improve Sexual Desire Decline 23 Acceptors (42,59\%) and those who do not improve Sexual Desire Decline by 31 Acceptors (57,41\%). And of the $30 \mathrm{~KB}$ acceptors whoripaired the change in orgasm were 46 acceptors $(85,18 \%)$ and those who did not experience orgasm difficulties were 8 acceptors $(14,82 \%)$. From the results of the bivariate analysis, it was obtained there were 43 acceptors $(79.63 \%)$ of the old implant KB acceptors and 11 new implant KB acceptors (20.37\%). The frequency distribution of implant family planning acceptors who experienced decreased sexual desire were 23 acceptors (42.59\%) and 31 acceptors (57.41\%). The frequency distribution of implant family planning acceptors who experienced orgasmic disorders were 46 acceptors (85.18\%) and 8 acceptors who did not experience orgasmic disorders (14.82\%). There is no relationship between implant table $K B$ acceptors and the incidence of sexual dysfunction (impairment of sex drive and orgasm disorders).
\end{abstract}

Keywords: Implant, Sexual Dysfunction 
CENDEKIA MEDIKA

P-ISSN: 2503-1392

E-ISSN: 2620-5424

\section{PENDAHULUAN}

Keluarga berencana (KB) adalah upaya untuk mengatur atau mengukur jarak anak satu ke anak berikutnya. Adapun salah satu metode kontrasipsi yaitu metode efektif. Metode efektif menjadi dua yaitu non hormonal dan hormonal. Metode kontrasepsi hormonal terdiri dari tiga yaitu suntik, pil, dan implant. Namun yang memiliki banyak penggunanya adalah suntik dan pil. Sedangkan pada kenyataannya implant merupakan metode kontrasepsi hormonal yang memiliki efektivitas sangat tinggi serta memiliki angka kegagalan yang rendah ${ }^{1}$.

Keluarga Berencana merupakan program yang meningkatkan peran dan kepedulian masyarakat melalui pengaturan jumlah dan jarak kelahiran dengan berbagai macam metode kontrasepsi yang telah tersedia. Kontrasepsi yaitu pencegahan terbuahinya sel telur oleh sel sperma (konsepsi) ${ }^{2}$.

Salah satu program keluarga berencana (KB) adalah untuk mengontrol laju pertumbuhan penduduk dan menurunkan angka kematian ibu (AKI). Sasaran program KB diantaranya adalah peningkatan prevalensi pemakaian kontrasepsi (Contraseptive Produktif Rate/CPR) menjadi $65 \%$, penurunan Pasangan Usia Subur/PUS tidak mau punya anak tetapi tidak mau ber-KB (Unmet Need) menjadi 5,5\%, dan peningkatan penggunaan Metode Kontrasepsi Jangka Panjang (MKJP) menjadi 26,03\%. Pada tahun 2014 target penggunaan MKJP yang diharapkan sebesar 26,03\% justru masih berada diangka $22,03 \%{ }^{3}$.

Di Sumatera Selatan dari awal JanuariOktober 2020 jumlah PUS yang KB aktif tercatat sebanyak 215.943 peserta dengan KB suntik $35,28 \%$, pil $23,75 \%$, dan implan $15,36 \%{ }^{4}$.
Pada tahun 2020 jumlah pasangan usia subur (PUS) kabupaten OKU sebanyak 79.731 jiwa. Dengan pengguna MKJP sebanyak 23.842 akseptor (29,90\%). Dengan pemakaian kontrasepsi terdapat pengguna kontrasepsi IUD $17,77 \%$, pengguna kontrasepsi MOP 0,42\%, pengguna kontrasepsi MOW 10,79\% dan pengguna kontrasepsi implant $71,02 \%{ }^{5}$.

Dari beberapa pengguna KB banyak pendapat atau mitos yang muncul di masyarakat tentang penggunaan $\mathrm{KB}$. Beberapa contoh pendapat yang banyak berkembang di Masyarakat yaitu penambahan berat badan, keringnya organ genital, wajah timbul jerawat, tulang keropos, dan badan menjadi tidak kencang. Dan ada juga salah satu mitos yang saat ini berkembang di masyarakat yaitu penggunaan $\mathrm{KB}$ implant dapat mengurangi kenikmatan senggama dan menurunkan kualitas hubungan seksual, yang dapat mengurangi keharmonisan rumah tangga ${ }^{6}$.

Berdasarkan data di Puskesmas Sukaraya tahun 2020 jumlah PUS 1359 jiwa, dengan akseptor KB aktif sebesar 1274 akseptor $(93,65 \%)$, dengan pengguna kontrasepsi pil sebanyak 333 akseptor $(25,75 \%)$, pengguna kontrasepsi suntik 546 akseptor (43,54\%), pengguna kontrasepsi IUD 92 akseptor $(6,53 \%)$, dan pengguna kontrasepsi implant sebanyak 117 akseptor (9,33), pengguna kontrasepsi MOW 13 akseptor $(1,03 \%)$, pengguna kontrasepsi MOP 0 akseptor(0\%) dan pengguna kontrasepsi kondom 173 akseptor $(13,79 \%)$.

\section{METODE PENELITIAN}

Dalam penelitian ini peneliti menggunakan metode survey analitik dengan pendekatan cross sectional, yaitu suatu penelitian untuk mempelajari dinamika hubugan antara variable bebas/independen (Akseptor KB Implan) dan variable terikat / dependen (Disfungsi Seksual (Gangguan Penurunan Hasrat Seksual Dan Gangguan Orgasme)) 
dengan cara pendekatan, observasi, dan pengumpulan data secara bersama ${ }^{7}$.

Analisa data menggunakan analisa univariat dan analisa bivariat dengan menggunakan tabel distribusi dan uji statistik Chi-Square, dengan derajat kepercayaan $95 \%$.

\section{HASIL}

\section{Analisa Univariat}

\section{Tabel.1}

Distribusi Frekuensi Variabel di Kelurahan Sukaraya Wilayah Kerja Puskesmas Sukaraya Tahun 2021.

\begin{tabular}{cccc}
\hline No & Variabel & Frekuensi & $\%$ \\
\hline Penggunaan KB Implan & & \\
1. $\quad$ Lama & 43 & 79,63 \\
2. $\quad$ Baru & 11 & 20,37 \\
\hline GangguanPenurunanHasrat Sexual & & \\
$1 . \quad$ Menurun & 23 & 42,59 \\
2. $\quad$ TidakMenurun & 31 & 57,41 \\
\hline GangguanOrgasme & 46 & 85,18 \\
$1 . \quad$ GangguanOrgasme & 8 & 14,82 \\
\hline
\end{tabular}

Dari Tabel 1 Dapat dilihat bahwa dari 54 akseptor KB implant, diketahui bahwa akseptor KB implant lama sebanyak43 akseptor $(79,63 \%)$ dan akseptor $\mathrm{KB}$ implant baru sebanyak 11 akseptor $(20,37 \%)$. Distribusi frekuensi akseptor KB implan yang mengalami gangguan penurunan hasrat seksual sebanyak 23 akseptor $(42,59 \%)$ dan yang tidak mengalami gangguan penurunan hasrat seksual sebanyak 31 akseptor $(57,41 \%)$. Distribusi frekuensi akseptor KB Implan yang mengalami gangguan orgasme sebanyak 46 akseptor $(85,18 \%)$ dan yang tidak mengalami gangguan orgasme sebanyak 8 akseptor $(14,82 \%)$.

\section{Analisis Bivariat}

Tabel 2

Hubungan antara Penurunan Hasrat Sexual dan Gangguan Orgasme dengan penggunaanKB Implan Di Kelurahan Sekarjaya Wilayah Kerja Puskesmas Sekarjaya Tahun 2021.

\begin{tabular}{|c|c|c|c|c|c|c|c|c|}
\hline \multirow{3}{*}{ No } & \multirow{3}{*}{ Variabel } & \multicolumn{4}{|c|}{ Penggunaan KB Implan } & \multirow{3}{*}{$\Sigma$} & \multirow{3}{*}{$\%$} & \multirow{3}{*}{$p$ value } \\
\hline & & \multicolumn{2}{|c|}{ Lama } & \multicolumn{2}{|c|}{ Baru } & & & \\
\hline & & $\mathbf{f}$ & $\%$ & $\mathbf{f}$ & $\%$ & & & \\
\hline \multicolumn{9}{|c|}{ Penurunan Hasrat Sexual } \\
\hline 1. & Menurun & 18 & 78,26 & 5 & 21,74 & 23 & 100 & \multirow{2}{*}{0,059} \\
\hline & Tidak Menurun & 25 & 80,65 & 6 & 19,35 & 31 & 100 & \\
\hline \multicolumn{9}{|c|}{ Gangguan Orgasme } \\
\hline 1. & Gangguan & 37 & 80,44 & 9 & 19,56 & 46 & 100 & \multirow{2}{*}{0,571} \\
\hline & Tidak Gangguan & 6 & 75 & 2 & 25 & 8 & 100 & \\
\hline
\end{tabular}

Dari Tabel 2 dapat dilihat proporsi dari 23 akseptor $\mathrm{KB}$ implan yang mengalami gangguan penurunan hasrat seksual, terdapat 18 akseptor lama $(78,26 \%)$ dan 5 
akseptor baru (21,74\%). Dan dari 31 akseptor KB implan yang tidak mengalami gangguan hasrat seksual terdapat 25 akseptor lama $(80,56 \%)$ dan 6 akseptor baru $(19,35 \%)$.

Hasil uji statistik Chi-Square menunjukkan bahwa tidak ada hubungan yang bermakna antara Lama Penggunaan KB implan dengan gangguan penurunan hasrat seksual dengan $p$ value 0,059 . Dikatakan tidak ada hubungan karenan $p$ value $\geq 0,05$.

Kemudian proporsi dari 46 akseptor $\mathrm{KB}$ implan yang mengalami gangguan orgasme, terdapat 37 akseptor lama $(80,44 \%)$ dan 9 akseptor baru $(19,56 \%)$. Dan dari 8 akseptor KB implan yang tidak mengalami gangguan hasrat seksual terdapat 6 akseptor lama $(75 \%)$ dan 2 akseptor baru (25\%).

Hasil uji statistic Chi-Square menujukan tidak adanya hubungan yang bermakna antara lama penggunaan $\mathrm{KB}$ implant dengan gangguan orgasme dengan $p$ value 0,571. Dikatakan tidak ada hubungan karenan $p$ value $\geq 0,05$.

\section{PEMBAHASAN}

Hubungan Antara lama Penggunaan KB implan dengan Gangguan Penurunan Hasrat Sexual di Kelurahan Sukaraya Tahun 2021

Dari hasil analisa bivariat, proporsi dari 23 akseptor $\mathrm{KB}$ implan yang mengalami gangguan penurunan hasrat seksual, terdapat 18 akseptor lama $(78,26 \%)$ dan 5 akseptor baru $(21,74 \%)$. Dan dari 31 akseptor KB implan yang tidak mengalami gangguan hasrat seksual terdapat 25 akseptor lama $(80,56 \%)$ dan 6 akseptor baru $(19,35 \%)$.

Hasil uji statistik Chi-Square menunjukkan bahwa tidak ada hubungan yang bermakna antara Lama Penggunaan KB implan dengan gangguan penurunan hasrat seksual dengan $p$ value 0,059 . Dikatakan tidak ada hubungan karena $p$ value $\geq 0,05$.

Menurut penelitian Heriani dan Dina Permatasari (2019) memiliki hasil bahwa terdapat hubungan akseptor KB hormonal (pil, suntik, dan implan) dengan gangguan hasrat seksual dengan hasil $p$ value $0.003^{8}$.

Menurut penelitan yang sudah saya lakukan menurunnya hasrat seksual, tidak hanyak disebabkan oleh pengguanan kontrasepsi tetapi juga disebabkan oleh kelelahan setelah bekerja, stres, ada masalah didalam rumah tangga bahkan ada penyebab lain. Dan dari hasil penelitian saya apabila hasrat seksual yang terus menurun ini yang kadang bisa memyebabkan stress wanita ataupun pasangannya.

Hormon yang berperan terhadap tinggi rendahnya libido wanita adalah hormon androgen dan estrogen, produksi hormon androgen dipengaruhi oleh adanya hormon estrogen. Pada keadaan stres berat, dimana jumlah estrogen menjadi berkurang, maka androgen pun menurun. Di situlah libido ikut menurun, namun tidak berpengaruh terhadap rangsangan dikarenakan rangsangan tidak dihasilkan dari sistem hormonal melainkan diberikan dari pasangan $^{8}$.

Faktor lain yang juga mempengaruhi turunnya hasrat seksual adalah pemberian kontrasepsi yang mengandung hormon progesteron yang menyebabkan keadaan vagina kering yang menyebabkan adanya gangguan pada lubrikasi yang dapat membuat turunnya hasrat seksual pada akseptor. Namun demikian, faktor psikis dapat juga berpengaruh dalam hal ini. Pemberian progesteron dalam jangka panjang diduga dapat menyebabkan tertekannya produksi estrogen. Mekanisme kerja progesteron yaitu menekan produksi Follicle Stimulating Hormone (FSH) sehingga menghambat peningkatan kadar hormone estrogen. Menurunnya kadar 
CENDEKIA MEDIKA

P-ISSN: 2503-1392

E-ISSN: 2620-5424

estradiol serum erat hubungannya dengan perubahan mood dan berkurangnya keinginan seksual bagi akseptor ${ }^{8}$.

Hubungan Antara lama Penggunaan KB implan dengan Gangguan Orgasme di Kelurahan Sukaraya Tahun 2021

Hasil analisis bivariat mendapatkan proporsi bahwa dari 46 akseptor KB implan yang mengalami gangguan orgasme, terdapat 37 akseptor lama $(80,44 \%)$ dan 9 akseptor baru $(19,56 \%)$. Dan dari 8 akseptor KB implan yang tidak mengalami gangguan hasrat seksual terdapat 6 akseptor lama $(75 \%)$ dan 2 akseptor baru $(25 \%)$.

Hasiluji statistic Chi-Square menujukan tidak adanya hubungan yang bermakna antara lama penggunaan KB implant dengan gangguan orgasme dengan $p$ value 0,571. Dikatakan tidak ada hubungan karenan $p$ value $\geq 0,05$.

Hasil ini sejalan dengan penelitian yang dilakukan oleh Heriani dan Dina Permatasari (2019) menunjukkan tidak pengaruh antara akseptor $\mathrm{KB}$ hormonal (pil, suntik dan implan) dengan gangguan orgasme dengan hasil $p$ value 0,547 .

Dari hasil penelitian yang saya lakukan bahwa tidak ada hubungan antara pengguna kontrasepsi implan dengan gangguan kepuasan saat berhubungan seksual, karena kepuasan tersebut bisa di berikan oleh pasangannya sendiri melalui perangsangan bagian - bagian yang peka terhadap sensasi seksual, seperti daerah vulva. Jadi orgasme wanita bisa diberikan oleh pasangannya itu sendiri dan tidak ada pengaruh terhadap pemakaian kontrasepsi implan.

\section{SARAN}

Dari hasil penelitian penulis maka penulis memberikan beberapa masukan untuk membantu dalam meningkatkan kesehatan ibu sebagai berikut:

\section{Bagi Peneliti}

Dapat mengaplikasikan ilmu yang dimiliki dan sebagai pembelajaran langsung di lapangan yang berguna juga dalam rencana pengabdian pada masyarakat.

2. Bagi Tenaga Kesehatan

Bagi instuti pelayanan kesehatan diharapkan dapat meningkatkan kualitas pelayanan kesehatan khususnya dalam memberikan pelayanan kotrasepsi implan dengan prosedur tetap konseling KB sebelum pemilihan alat kotrasepsi, serta meningkatkan perannya dalam memberikan informasi tentang efek samping kontrasepsi KB Implan.

\section{DAFTAR PUSTAKA}

1. Thoyyib Tb Dan Yunik Windarti. 2014. Hubungan Antara Tingkat Pengetahuan Tentang Implant Dengan Pemakaian Kontrasepsi Implant Pada Akseptor Di Bps Ny. Hj. Farohah Desa Dukun Gresik. Vol. 7 No. 1 (2014): Jurnal Ilmiah Kesehatan (Journal of Health Science). https://journal2.unusa.ac.id/index.php/J HS/article/view/437

2. Nugroho, T dan Utama I.B. 2014. Masalah Kesehatan Reproduksi Wanita. Yogyakarta: Nuha Medika

3. BKKBN. (2015). Pembangunan Kependudukan dan Keluarga Kecil Berkualitas. Jakarta: BKKBN.

4. BKKBN-PP. (2018). Tingkat Prevalensi Peserta KB Tahun 2018. Palembang: BKKBN.

5. BKKBN OKU (2020). Cukilan Data Program KeluargaBerencana (KB) KN Nomor 246 ISSN : Palembang

6. BKKBN. (2015). Hasil Pelaksanaan Sub Sistem Pencatatan dan Pelaporan Pelayanan Kontrasepsi. Jakarta: Direktorat Pelaporan dan Statistik

7. Notoatmodjo, Soekidjo, 2017, Metodelogi Penelitian Kesehatan, PT Rineka Cipta, Jakarta. 
8. Heriani dan Dina Permatasari. 2019. Hubungan Akseptor KB Implan Dengan Disfungsi Seksual (Gangguan Penurunan Hasrat Seksual Dan Gangguan Orgasme) Di Wilayah Puskesmas Sekar Jaya Kecamatan Baturaja Timur Kabupaten Oku Tahun 2019. Volume 7, Nomor 2, Desember 2019. https://jmm.ikestmp.ac.id > article > downlod 